\title{
雑草とその防除に関する諸問題
}

\section{近藤 萬太郎先生の回顴}

网山大学農栄生物研究所 笠 原 安夫

\section{Yasuo Kasahara : Reminiscences of Dr. Mantaro Kondo}

戦前，世界的に存在が知られていた財団法人大原農業 研究所(現在，岡山大学農業生物研究所)は1914年に大原 孫三郎氏の察附によって設立された。近藤蕾太郎先生は 農研創立頭初から御逝去の時まで32年閒所長であった。

先生の御業樍意思 へで見るに，先生の 誠実, 几㖘面な御性 格ときわめて装捧㧧 く一貫した御努力が 「ブラシカ属の種子 について」(1909)の 御研究発表以後, 30 余年間にむのされた 諭文は実に 500 余篇 という大へんな数に なった。そしてその 種子研究の集大成が 名著の「日本農林種 子学前編467頁, 後

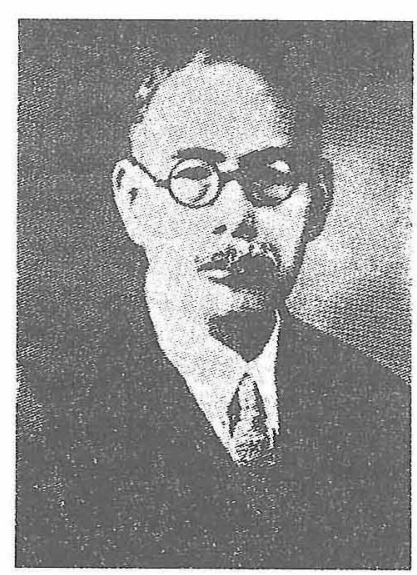

図 1 故近藤萬太郎氏先生
編 885 頁の大冊であるが(1933〜34)，そのなかに収めら れた種子の形態，解剖図 357 のうち殆んどが先告自身の 描図である。また「米嵘の性状と貯藏」は平易に書かれ た著書である。それらは現在に拉いても斯界研究を志す 者にとって最高の道標である。それらの論文, 著書の原 稿は全部合せば何万枚だろらか，全部が先生自から毎日 コッコッ書かれた珠玉の結晶である。

一方先生はこの研究と平行して研究所運営の責任と所長 事務も十二分に遂行された。そして，所長としては研究 員には何の干渉もなく，その研究摆題が農業に直接すぐ 役立か否かを間わず全く本人の創意之自由採択に任せら れた。いつしかその自由研究が農研のモットーとなって よい伝統が築かれた。

大原農研注研究者にとって精神的な研究環境がよかっ たのか，勤務者の大方がかなり長期の勤続であり，そし て当所に籍を招いて研究した者のうち22名が学位を得, 約半数がそれぞれ專門の学会賞を受けている。私立の研 究機関として注しいようだ。これも，近藤先生の御仕
事振りが無言の教訓となっているのではあるまいか。 研究に対する先生の日常の御主張は「実際農家に役立二 農学研究」であった。そして学術的研究の外に実際的研 究がきわめて多い。また農業経営, 農政, 教育について も論文がある。「農学栄えて農業裏える」という日本農 業の現実について，先生は常に心痛され，時々等者達助 手にもこの言葉老洩らされていた。助手にとっては，立 派な䯿(学生時代髹の圆チャンのニックネームがあった) と貫録ある先生泣一見こわい存在であったが，接する者 に対しては温情，筧大で，実釦について慎重さを要求さ れた外は大まかで，原稿用紙に大きな字で实験要項と文 献を示される程度で実に体び々々して実験することが出 来た。

さて筆者がここに述べんとする近藤先生と雑草研究て あるが，先生の雑草研究への御関心法余程以前からあ。 たようでそとの最初の記述はすでに1934年発行の前記 「日本農林種子学」後編の例言 4 に「㺘草種子の記述は 2,3 を除く外全部省略して他は杂草種子篇の著述に培り たり」と記されている。

筆者が雑草研究に入ったのは，先生の助手として農研 に入所 2,3 年後の 1932 年頃だったと思う。当時筆者は日 曜日，休日その他闌さえあればドーランを育に野外植物 を採集しに歩いていた。また牧野富太郎先生，田代善太 郎先生などによる県下の植物指尊採集会には努めて参加 していた。或る日，先生から等者に，君は植物分類を勉 強しているようだが，雑草種子も採集し，その形態と発 芽をしら心゙，見透しがつけば，薬剈で雑草を駆除する試 験をはじめたらよかららといら話があった。管者が雑草 種子を採集して最初の仕事は，近藤先生との共著「栗，

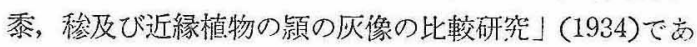
った。それにはキンエノコロ，オオエノコロ，ハマエノ コロ，エノコログサ，ムラサキエノコロ，アキメヒシ バ,メヒシバ, ミズビエ, ノビエ，タビエ，スカキビ, ハヒヌメリ、ヌメリグサを供試した。

農家出身の筆者は農作業に㧍ける除草作業がいかにつ らいものか体験しているので，この問題を授かって喜ん だ。しかし「種子の䝪蔵」「米考の䕗品による品種鑑枵! 

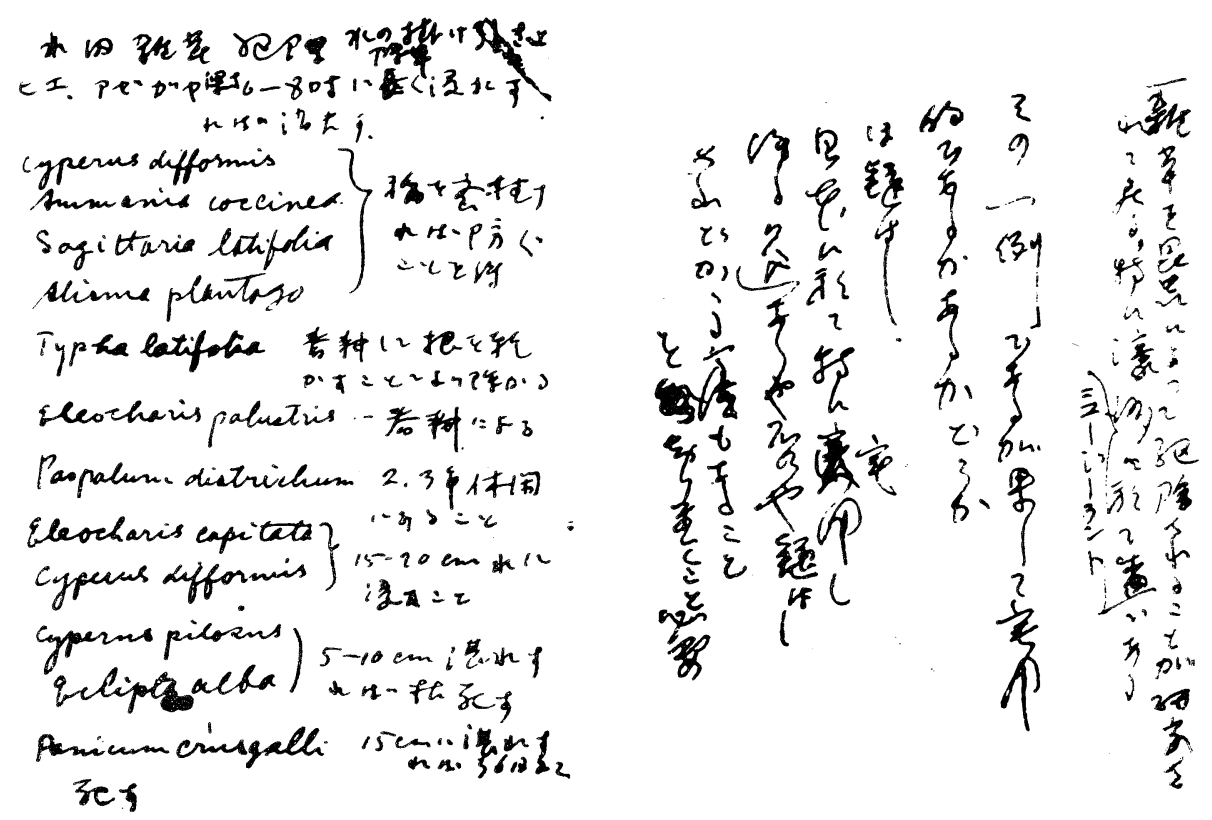

図 2 近藤 先生のメ三の例

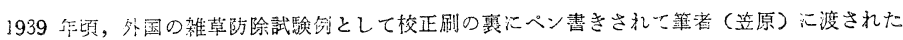

その他无手掛汗ており，身分が助手なので専念出来ない 立場でも亦り，来た当時は雑草文献は少なく，地味な仕 事なのでなげ出したい上思ったことも一，二度ではな ふった。先生は君は若いのだからこの仕事を20年つづけ 和菭成果が出る上言われた。20年も研究をつづけるなん て夢のような話と思ったが，しらべている内に雑草の種 類, 地理的分布, 種子の発芽と環境の関係が少しわかり か㲿た。ふか门かけると面白いので一時は相当に熱中し た。しかし戦争が注じしなるにつれて雑草分布調查旅 行むきつかしくなり，薬剂入手も图難で，或る時は人絹 工場廃液沈澱物を兌って実験したり, 海水を $3.4 \mathrm{~km}$ 離 祀水島，呼松海岸に自転草に石油鑵をつんで運び，熱 こ一撒布したりした。いろいろ起伏があったが，30年を 渦きた今日，先生の言葉を思い出すと末だ十分成就して いるといえないのは筆者の不敏もあろうが，恐らく先生 上して注20年は最短期間を言われたものであ万う。先生 ままた「農学研究」には君と共同研究として発表する が，君が主にやった仕事は学会には単独で発表せよと言 うれ，また「農業及園芸」などへの投稿についても紹介 ミれ，つ之めて助手の仕事に対して張合をもたせるよう こ考虑されていた。

先生の雑草研究に対する御考えは次に示す 2,3 論文の 緒言によくあらわれているので，それらをそのままかか げておこう。先ず雑草種実に関しては「雑草種実の研究」 第一報(1935)に，「種子学に於ては，藏に農林業園芸に
用ふる種子, 或法薬用汇供せらる種子等, 所僵有用種子 につきて研究するのみならず，同時に農業園芸に害すな す所謂雑草種子につきても研究すること肝要なり。農業 園芸に於て労力の大部分を占むる涂草にして, 除草を 急らんか, 生産物の品質を落すは勿論, 収穫を減し, 或 は時に皆無上なるこ上ありて, 病虫害駆除を意りし:異 らず，さら染䧴草の研究は植物の疾病及び害虫につきて 研究すると同一にして敢て軽重なとと云う心し。然るに 今日雑草につき七の研究少なきは, 正に農業の進歩に於 ける大なる欠陥之云うべし。雑草の研究につきては, こ の植物の一般性状及び加害の程度, その駆除の方法につ きて研究するすのなるが，その種実につきて研究するこ 上は, 就中最も䀒要なり。種子を研究して, その結実伝 播を防止し, 或は土中の種実を殺し, 或は採種に際して 雑草種子の混入防ぎ, 或注種子検查によりて有害雑草 を鑑識して，苟も之の混入せる種子の蒔き付を禁止する が如き方法を講ずれば，田野園圈に雑草の繁茂を防き， 労力を節約し, 生産物の品質を向上せしめ, 収量を多人 するに多大の効果を齊すべし。今日欧米にては雑草の研 究と共にその種子につきて研究するもの無きにしもあら ざれど, 敢て盛んなり上云う能はず, 又本邦にても，か かる研究を未だ多?見ず。近藤は多年本邦の雑草種子に つきて研究せんこ上を志したるも, その時期に到達せざ りしを遺憾々するここ久し。著者等今日漸くこの方面の 研究に手を染めんこして, 最初に岡山県にし普通に見方 
るる禾本科雑草15種の種実につきて研究をなして，蓄に 記載せんとす」とある(193 種について発表)。

また雑草種子の発芽については，「雑草種子の発芽の 研究（1）」（1941）に「雑草は環境に対する適応性強大 こして，自己維持の性質強し。又多くは小粒種子を多数 こ生じて撤布し易からしめ，且つ生長期間短かく，繁殖 力旺盛なるが故に，自から容易に繁茂するなり。されば 農地に於てその管理を怠る時は，雑草は忽ちに農作物を 王倒し，作物の減収を来にすに到る。四時農業労作の大 部分は除草にあるが故に，雄草の駆除は肝要なる研究事 垻にして，满虫害の研究に比するに，气の重要程度に於 下湤て劣るものにあらず。而して雑草種子の発芽は之 の根本問題の一と云う心し。本研究は杂保草種子の発芽上 その環境との関係を知らんが為めに，特に光線及び変温 デ発芽に㪀ぼす影響を試験したるものなり。」しある。

(その㖟筆者が引つづいて研究して種類を合せて116 種 在供試した。)

号に薬剤による雑草の駆除に関しては，一薬剤によ る雜草の䍗除試験第一報」(1942)に「雑草の駆除には耕 埲除草を適期に，乙かも頻繁に行うを最良となすは云う 辛俟たざるが，近時労力不足の為め之が実施漸く困難文 加う。よって䇰力的除草作業に代うるに，化学薬品を撒 布して簡単に除草し得れば農業経営上甚だ利益ありと云 うバしさされば欧米に於ては以前より薬剤除草に関する 研究行方る。耕地にあらざる土地の薬剤除草は簡単に行 うるれど，耕地においては作物に無害にして，乙か子雑 草を除くものなるが故に，実際には困難なる事明かな 门。輓近医学に人体内の種々病原菌を薬剤にて殺す療法 が研究せられ，化学療法が最近にしかも盛んに行わるる が，此薬剤も人体に無害にして，病菌のみを殺す特性を 悀へざるべからざるが故に，その療法は困難なるべし。 されど化学療法は現時着々と進行しつつあり, 惟ふに雑 草駆除も亦之と同じくして，適当の薬剤を作り，適当の 時時及び方法に於て撒布すれば，その目的を達するなら え。されば欧米においては以前より，此の方法につきて 研究せられたるは宜なりと云うべし。然るに未だ本邦に 於ける研究は十分ならず。依て著者等は茲にえが研究を 行わんとして努力しつつあり。」と記されている。

晚年の先生は御多難であった。戦争の進展は農学者専 攻されておられた御三男の戦死に遭われ，米麦の研究に 従事されながらも食糧㺃による㿥養不良上なられた。し 加も, 学力不足のため研究所 2 町歩の水田の田植にも出 られたりした。研究所産米麦を食用に上 1,2 淮言した向 もあったが先生は御聞き届けがなかった。今にして思六 ば，筆者たちが気のきかないばかりに田植をお止めしな
かったここ在悔んでいる。こうした御無理が先生の健隶 立さしばみ，このため終戦直後から翌春まで卧床され た。一時はかなりよくなられ，出勤されたが，先生を待 ちうけていたものは敗戦後の世相の急変であった。財団 法人さしての所有田畑の解放で収入が絶え, 所員達の乙 の生活, 研究所の現状, 前途に対する不安からいろいる な改革案, 待遇改善を所長にせをった。自から創立以来 築き上げられた研究所の佗機再建记対する先生の心痛注 御病気の再発上小り, それから6 ケ月の薬䬺生活の後, 1946年11月7日に御逝去になった。

筆者は近藤先生の回顧記を綴る今日, 机の下から図ら する御病中の先生からいただいた御手紙 2 通を見出し た。一通は御逝去 4 万月前の 7 月 4 日，一通は 5 日前の 11月2日付のむのである。今日はっきりした記憶がない 吕，4 方前のもの流, 筆者の研究生活の不安 (当時收 入のない研究所の所員の給与はきかめて低かった）を聞 き伝えて帰郷をすすのる郷里の人達の勧誘もあったので 今後の仕事之身の振り方について御指示を仰いだときの 御返事であった。

私の病気も永くなりましたが次第に元気になって居 ます。半起半床であるが気管支カタルが執拗で中々治り ません。之が直ら妨勤めに出ることは出来ませんから 幸抱して居ます。御心配下さらぬ様に願います。

研究所の職員も西門副所長（西門義一博士）の所で人 事移動をなして転出者も相当出来ますが, 貴君は落ち着 きて胻来の通りに研究して居り下されたし。人事移動は 副所長に一任して居ります。研究方面は従来の如く種子 雑草種子, 雉草駆除及利用等に向っ下單独で研究を遂行 して随時何所でも発表して置き玉へ。農学研究は何時出 版になるか今の処判然しない(後略) 7月4日」

また5日前のものは種苗協会から先生人研究を依託し て来たので一時海引受けになるつき门で，小生に上京 して交渉するようにこの御話があったここに関するもの であった。

「择復小生の病気も一進一退ミ゙容易に全快しません。 そこで此儘では職務も勤まらぬのだ実は内秘ではあるぶ 辞表を出しました。そういう訳て今更新に種苗の研究を 引き受けるこさは小生の良心的責任感上出来ない故乍遺

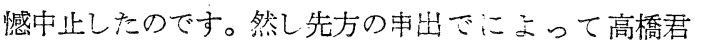
(高橋隆平博士)と貴君しで引受け一きミンと云うこ上に なれば別に話を進めればよろし、、思う。先方の考えは 当方人事 (種苗専門家) につきて先方汴信用するかどう かの程度です。小生の相談した趣旨汶数年間に数多の種 子專門家を作っておけば今後の種苗改良に貢献する故に 予算の都合では新採用新養成の漬りー寺った。尚他の理 
昌は研究よりも実畋に本邦の事情に適するよらに種苗検 查而び種苗貯蔵を具体化することでかった。是迄の文部 省の補助金とちがって実際の種苗研究をなして実地に適 用することであった。右御返事泾，11月2日」

御他界数日前にも日本の種子検査のこと，また研究所 辞任によって依託試駼が実施出来ない責任感など先生の 御面目がよく現れている。

近藤先生を回顧しながら笋者の思いは次のようなこと に走る。(1)戦前から選抧的除草剂の出現在予想せられ た先生が，2.4-Dを見ないで御永眠されたことである。 (2)筆者に対して雑草研究の御指示のうち雑草利用が未断 だ殆んど未着手のこと(3)すでに 27 年前に農家にとって 雑草駆除の重要性注病虫害研究のそれに比べて優るも劣 るものでないことを指摘されているが，現状はどらだろ らか，なるほど，除草剂の発展によって先生在世中の夢 が実現し，乞の使用面積120 万haにも及んでいて，可成 り多数の人達がその試験䣲究に従事していて隔世の感が 㐫る。しかし雑草研究の基礎方面の研究費, 專任者流 話になら程少ないものだろう。農作物, 家畜の病虫害 研究に多数の專門研究者をようしての研究に比べて, 雑 草学講座一つもない現状である。研究投資の多い面に優 秀な研究者が集り発展するのである。最近雑草防除研究 のムードが高まり,本会創立もその一つの現れで方が， 本会の発展と共に研究機関, 大学において雑草研究室を 設置し，多数の専門家の養成を期待したい。現在アメリ カでも雑草防除研究者は総数で 125人（兼任 275), 最近 10 年の研究費総額 150 万ドルで, 害虫学研究者は専任 研究者 4,500 人, その研究費は雑草防除研究費の 20 倍, 3,000 万ドルであるという。しかし, もし雑草防除科学 に不足のない科学者をようし，専門家をつくるに適当な る訓練が行なわ礼るならば次の50年間において雑草研究 は他のどの科学よりも農業界に大きく貢献するにちがい ない。

\section{○近藤萬太郎先生の御略歴}

1883年 岡山県邑久郡豊村 (現在西大寺市) で出生

1908年 東京帝国大学農科大学卒業

今らに2 ケ年半大学院で稻垣乙丙教授のも こで種子学専攻

1911年 ドイッ, ベルリン大学留学, ウイトマック 教授 (Prof. Dr. L. Wittmack) のもこで 種子及び禾款類の品種分類を听究，翌年ホ 一ヘンハイム農科大学に大学

1914年 帰朝, 大原農業研究所設立に参与, 所長に 就任
1946年 逝 去

その間, 33才で農学博士, 38才で学術研究会議員 45才の時に日本農学賞, 47才の時に岡山後湶園行在 所で「稲及米に就きて」御前講演奉仕，49才の時チ エッコスロバキヤ農学々士院会員, 64才（晚年）の 時に帝国学士会員，なお 1923 年第 2 回北大平洋学術 会議(豪州)，1928年第 5 回万国種子協会会議 ( マ), 万国種子学術研究会議 (ブラッセル) 出席。

○近藤先生のエピソート

先生の父上は先生が 6 才の時御他界, 御兄弟は母 上御一人で育てられました。先生は幼時上りおとな らしく何時も村の集会など子供ながら一人前の役を 務め, 読書欲, 向学心強く, 漢籍を学び, 史記, 左 伝，春秋を読み，左伝を恰も活版印刷せる如く美濃 秖に写本された。岡山中学校に大学当初は一時岡 山に下宿されたが，母上の御病気以来孝心深き先生 は毎日草鞋ばきで往復7里を家から徒歩で, 5 ケ年 間, 早朝と日の短い夕は提灯を下げ通学された。汽事 のない沿道の村人は先生の提灯で夜明けの時刻を知 り「邑人郡の汽本」と名付けた。また大学駒場寮の 学生仲間は「鳥の鳴かない日はあっても君の姿が図 書室に現れ昍はない」といい，「クラス第一の勉 強家であった」と。

研究所へは時計の針のよらに定刻 5 分前出勤, 5 分後御退出が日課で, その間お客以外の㭙は実験, 執筆, 読書の連続であった。先生は幼嚇から小, 中, 高, 大学時代, そして一生を無類の根気で貫かれた。 それが面倒で人のやらない種子学，款物学などであ の膨大で綿密な研究成果を生んだにちがいない。唯 一の御趣味である漢詩作りもこの伝で每日読まれた と承っている。

\section{○大原孫三郎氏と近藤先生}

大原氏は倉敷市の富豪, 敬堂と号す。倉紡創業社 長, 本業の外, 若い時から社会福祉増進に関心をも ち岡山孤児院経営の石井十次郎氏を後援した。また 倉敷中央病院を建て, 学門芸術の面では, 大原農研 の外, 大原社会問題研究所, 倉敷学働科学研究所, 大原美術館を創立, 郷土の生んだ不世出の先覚者, 文化の保護者として大きい足跡を残した。また，人 材を世に送り出すため大原家奖学金制度をつくっ た。たまたま近藤先生の六高在学のころ, 農業の将 来に大きな関心をもち, 先生の人となりを見こんで 農科大学に進学をすすめた。以後先生は氏の知遇と 寄托に心からこたえて農業の発展のため研究所をた て, 育て, 守られた。ちなみに氏より奨学金を受け 
たものは県下で40名近くあったが，氏の寄托にこた えたものは僅かしかなかった。
附記 本記は近藤萬太郎追憶集（1958）より引用した ところが多い。

\section{生 物 教育からみた 雑 草}

千葉県習志野高校延原肇

Hajime NoBuhara: Weed as the Teaching Materials of Biological Science

\section{は しがき}

雑草交我々の身近にみられる植物でありながら，その 割に関心を持だれていない。中学生, 高校生がどんな研 究テーマをとりあげているかをみ就ば，彼等の関心がど こに向けられるかがわかる。このため第 5 回学生科学賞 応募テーマ, 高校共同研究コンテストに応募したテーマ, 和歌山県日高高校の一年生に課しだ自由研究のテーマを ながめてみた。

第 5 回学生科学賞には生物関係のテーマでの応募数汁 中学 1,063 点, 高校 179 点であった。内容がわからない ので多少のまちがいがあるかもしれない。このうちで雑 草在対象にした研究は, 中学 10 点, 高校 6 点であった。 即ち中学ではわずか $0.9 \%$, 高校で $3.4 \%$ である。中学 では 8 点が生態， 2 点は防除汇関する研究で，高校では 防除が 3 点, 生態が 2 点, 生理が 1 点である。農業高校 の研究は全部防除に関する研究で, 普通高校の研究は生 態, 生理に関する研究で，特色がはっきりしていた。雑 草に関する研究は極めて少い上に，中央審查をうけた優 秀な研究は 1 点もなかったことからみて，あまりすぐれ た研究でなかったと思われる。高校共同コンテスト第 4 回, 第 5 回の応募テーマをみると, 生物に関する研究は 29 点で，このうち雑草の研究は「水田裹作麦雑草の生態 とその防除法」ただ一つである。これは第 5 回に三等に 入選したが，本格的ないい研究である。和歌山県日高高 校の自由研究では, 約 250 人の研究で雑草を研究したも のはなかった。雑草はこのように, 中学生, 高校生に忘 れられた存在である。彼等の目は特異なもの, 珍らしい ものに向けられ勝ちであり，見なれたものには向けられ ていないことがはっきりする。

この傾向は学生だけであろらか。生物教育においても 生物学者にとっても, 雑草は忘れられた存在である。生 物教育においては, 生物教師は雑草を無視しょうとして いるのではない。銚子市の理科の研究グループに，空地 の雑草の野外指導さしたとき，大変感謝されたことから
みても，多くの生物教師は雑草の知識を要求しているこ とがわかる。なぜなら生物教材として多くの洒值を持っ ていること彼等は知っているからである。身近な出来 事孝はっきりっっこんで教えることは，子供たちにより 大きな満足とよろこびをあたえうると，教師たちは知っ ている。生徒が雑草に無関心なのは教育を受けなかった ためであり，そのために身近な事を軽視するくせがつい ただけなのである。身近な事を軽視するくせは，自己卑 下の心と相通ずる。即ちこれは教育の本質に相通ずる重 大な問題である。

\section{生物教材としての雑草}

雑草は，形態及び生態教材としてすぐれた面をもって いる。主にこの点について断片的であるが述べてみた い。現在の形態教材は単にこんな形のものがあると，種 々の形のものがならべてあるに過ぎない。形態は系統や 機能と関連さして扱われねばならない。このようにまと めた試案を次にかかげ，このようにまとめると雑草の教 材的価值がクローズアップする点について簡単に述べた w。

下等な植物は全部が柔組織から成り立っている。この ような植物は水が多量に存在する場所にだけ生育してい る。形が小さい藻類は根茎葉の区別がないが，このよう な形態分化は大型化に伴ら支持機能の増大の必要とむす び付いている。陸上生活をするものは，水中生活をする もの上り，支持機能を強く要求される。さらに通導機能 も要求され管束の分化が起る。重要な機能である水，肥 料の吸収，炭酸同化，窒素同化，蒸散作用，養分の貯蔵 は柔組織で行われ，管束はサービス的な役割を果す。植 物にとって最む重要な根の先と葉は大部分柔組織ででき ている。古い根と茎の働は，通導作用と支持作用で，そ の役割は管束に代表されている。このようにまとめると 根茎葉の構造が理解しやすくなる。又伸長に応じ, 支持 と通導の作用がさらに要求されることと二次組織は主に 管束の増大により形成されることと対応するものであ 